\title{
EFFECTIVENESS OF ORGANIZATIONAL WORK IN PUBLIC ADMINISTRATION
}

\author{
Nitta C. Sasmita ${ }^{1}$, Charisma A. Fitrananda ${ }^{2}$ \\ ${ }^{1,2}$ Universitas Pasundan, Indonesia \\ Inittasasmita@gmail.com, ${ }^{2}$ charisma.asri@unpas.ac.id
}

\begin{abstract}
Organizations that are private in carrying out activities, the emphasis lies in getting a profit or profit, therefore proper organizational activities and can achieve optimal goals can be realized, so that waste is avoided and all the potential that is owned will be more beneficial for the achievement of common interests. This includes higher education organizations. Administrativeactivities are generallyassociatedwithplanning, organizing, controlling, placing, directing, motivating, communicating and making decision activities carried out bye achorganization with the aimofcoordinating various resources owned by the company, so that a productor service will be produce defficient. In such circumstances, in carrying out their duties, without exception all member sof the organization need to work to gether in order to lead to the achievement of the main goals of the organization. All these different activities can be harmonized with one another and gohand in hand to ward the ultimate attainment which is directing and harmonizing. Organizational effective nessis the result of work that is right on target and effective in accordance with predetermined planning or in accordance with the desired results at various levels of the organization in order to achieve mutually determined targets. This research states that the main influencef actors on organizational effectiveness are Organizational Characteristics, Environmental Characteristics, Characteristics of Workers and Management policies and practices. The formation of work units in anorganization is an attempt to achieve goals. The work unit must always have a main task and function as a basis for determining plans.
\end{abstract}

\section{Keywords: effectiveness, public administration}

\section{Introduction}

Modern humans always unite themselves in organizations in order to be able to actualize themselves in achieving their life goals. Human efforts to cooperate systematically in the sense of deliberate, planned and directed towards a goal, is called an organization. The complexity in the organization from day to day continues to increase and requires a new dimension in modern management in the face of change and its consequences. The main task of management is to try to ensure and plan everything, especially those related to changes outside the organization which ultimately necessitate a strategic change in the organization in order to survive which is equipped with strong human resources.

The success of the job really depends on all parties involved in the achievement of organizational goals, both in government and private sector in carrying out their duties in accordance with the management functions implemented correctly. One of the management functions that must be considered is coordination, which plays a

very important role in determining the steps an organization takes to achieve its goals. Coordination is one of the management functions in carrying out these various jobs appropriately, quickly and effectively to reduce errors.

Coordination can run effectively if it is carried out by an administrator who is able to adapt a variety of tasks from light to complex ones. All of the organization's activities run smoothly and simultaneously or simultaneously depending on the administrator's ability to mobilize the people around him. Every member of the organization has onei special expertise as an aid in the effort to achieve the main goals of the organization.

Administrative activities are generally associated with planning, organizing, controlling, placing, directing, motivating, communicating and making decision activities carried out by each organization with the aim of coordinating various resources owned by the company, so that a 
product or service will be produced efficient. In such circumstances, in carrying out their duties, without exception all members of the organization need to work together in order to lead to the achievement of the main goals of the organization. All these different activities can be harmonized with one another and go hand in hand toward the ultimate attainment which is directing and harmonizing. That act of directing and harmonizing is called coordination.

Coordination is the task of the administrator at the top level of the organization for subordinate activitiesnnya. Group activities carried out with the awareness of cooperation can be called organized activities which in modern society would be carried out in a more formal arrangement. All of that is intended to achieve work results at various levels in order to achieve organizational effectiveness.

Organizational effectiveness is the result of work that is right on target and effective in accordance with predetermined planning or in accordance with the desired results at various levels of the organization in order to achieve mutually determined targets.

Organizations that are private in carrying out activities, the emphasis lies in getting a profit or profit, therefore proper organizational activities and can achieve optimal goals can be realized, so that waste is avoided and all the potential that is owned will be more beneficial for the achievement of common interests. This includes higher education organizations.

Coordination as one of the administrative and management functions in organizations that many experts have put forward through their theory, such as regarding the organization with the implementation of coordination to achieve organizational effectiveness.

Mooney in Moekijat (1994: 25) states that "coordination contains all the principles of effective organization and organizational goals". In other words, one of the reasons why members' activities are organized is that coordination can be obtained. Among the final results of coordination which is very important is the determination of the relationship between the power organizational units delegated to their respective organizational units, one of which is vertical coordination.

Handayaningrat (1984: 90) states that: Vertical coordination or structural coordination, where there is a hierarchical relationship between those coordinating and structurally coordinated. It can also be said that coordination is hierarchical, because one another is on a line of command.

Although generally it has been recognized the importance of coordination in administrative processes, the reality is that in practice it is not uncommon for various problems to occurThis results in ineffective implementation of the necessary coordination, so that the achievement of goals / objectives does not always go as expected.

The scope of vertical coordination suggested by Sugandha (1991: 26) states that Vertical Coordination is the coordination between officials and between lower-level units by superior officials or direct upper-level units, as well as branches of an organization by the parent organization.

Seeing the importance of coordination for an organization, Stoner and Freeman in Nitisemito (1996: 14) suggest: "Without Coordination individual and department would lose sight of their roles within the organization" it is recognized that without coordination, individuals or sections will lose work guidelines (handles) about what must be carried out in the organization, in connection with which there is a need for planning coordination, organizational coordination, coordination of movement and coordination of control as the basis of the entire organization which is expected to maximize resources in order to achieve organizational goals.

An organization without a coordination can be said to lose grip because it is the control of the entire organization which is expected to maximize resources to achieve goals.

Sugandha (1991: 26), put forward the principles that need to be applied in creating Vertical Coordination, namely as follows:

1. There is agreement and a unified understanding of the goals that must be achieved. 
2. There is an agreement regarding the activities or actions that must be carried out by each party, including targets and schedules.

3. There is obedience and loyalty from each party to their respective duties as well as a predetermined schedule.

4. From the exchange of information from all cooperating parties regarding activities and results.

5. There is a coordinator who can lead and mobilize and monitor this collaboration, as well as lead joint problem solving.

6. There is information from various parties flowing to the coordinator so that the coordinator can monitor all implementation of the collaboration and understand the problems currently being faced by all parties.

7. There is mutual respect for the functional authority of each party so that there is a spirit to help each other.

Sugandha (1991: 14) also argues that the elements of coordination are as follows:Units or organizations, Potential sources, Unity, Motion of activities, Harmony and Same direction (target). The elements of vertical coordination that are stated are absolute, and if one of these elements is not present, coordination activities will not be effective. Thus the elements of vertical coordination are a system that is inseparable from one another and is a unified whole. Obviously these elements are benchmarks for coordination activities, so it can be said that the success of the organization in achieving goals or objectives is determined by the existence of these elements.

Another principle that is most frequently highlighted is the principle of coordination. This fact is understandable because it is much easier to say than to apply. The fact shows that in organizational life, everyone agrees on the absolute need for coordination for the achievement of goals and for the implementation of operational activities in an efficient and effective manner. But when it comes to its application, the behavior and behavior that are seen often indicate that there are still various problems. In other words, problems related to vertical coordination cannot actually be seen only as something technical in nature, but rather are perceptions, mental attitudes and behaviors. The concept of vertical coordination is closely related to the effectiveness of organizational work.

\section{Method}

Research that is done using qualitative research design research that is research that focuses on certain phenomena that do not have generalizability and comparability but have internal validity and contextual understanding (A, Chaedar alwasilah, 100, 2012) or qualitative methods are also referred to as methods that are more easily adapted to various kinds of interrelated realities. While the research method is done descriptively, namely questioning what actually happened about the behavior or event as observed (or potentially observed) by the researcher. (A. Chaidar Alwasilah, 94: 2012). The object of this research is the work experience in administration public.

\section{Result and Discussion}

The effectiveness of a person in trying to achieve goals in every social atmosphere, not only in his own activities but also how the activity relates to what is being done by others. Coordination is considered as a tool to adjust the activities of a person or unit, unit, part with one another and to create cooperation.

Steers (1985: 209) states that the main influence factors on organizational effectiveness are Organizational Characteristics, Environmental Characteristics, Characteristics of Workersand Management policies and practices. The formation of work units in an organization is an attempt to achieve goals. The work unit must always have a main task and function as a basis for determining plans.

Siagian (1982: 225) sees six variables that need attention:

1. Origin of the Organization

2. Organizational Legality

3. "Health" Organization

4. Organizational Growth

5. Personality

Organizational change and development will be carried out steadily if within the organization there is a philosophy that is oriented to the importance of the human element, as the subject and object of the organization, which in carrying out its activities is based on a mature plan with a clear priority scale, a program that is clearly spelled out from the plan. which has been 
determined and supported by an adequate budget and filled by personnel who are loyal to the organization, have strong discipline, knowledge and skills that are in accordance with the mission of the organization and have behaviors that lead to the creation of a healthy organization.

Vertical coordination which is expected to develop the organization will then be followed up with organizational effectiveness to achieve maximum results for the organization. Effectiveness can be termed the useful results, in other words that effectiveness is the achievement of a predetermined goal.

Organizational goals can be achieved effectively if they pay attention to the various factors that determine these activities and are adjusted according to needs.

Gibson, et al in Djoerban Wahid (1997: 32)

argues that organizational work effectiveness has the following dimensions / indicators:

\section{a. Productive}

Productive describes the organization's ability to produce the quantity and quality of output in accordance with environmental demands. This concept does not include considerations about efficiency. Measures regarding production include profit, sales, basic parts, students who graduate, documents processed, customers served, and so on. This measure is directly related to the output consumed by the organization's customers.

\section{b. Efficiency}

It is defined as the ratio (ratio) between output and input. This criterion focuses attention on the entire input cycle of the output process, however, this criterion emphasizes the elements of input and process. Efficiency measures include the rate of return on capital or assets, cost per unit, periods of inactivity, and so on. It is clear that it is a measure of profit and cost or output or time.

\section{c. Satisfaction}

Formulating the concept of organization as a social system requires that we pay attention to the benefits received by the participants and customers. Satisfaction and morale are similar terms, which indicate the extent to which the organization meets the needs of its employees. Satisfaction measures include employee attitudes, employee replacement, tardiness and complaints.

\section{d. Adaptation}

Adaptability is how far the organization can respond to internal and external changes. Adaptability is more abstract in nature, because it relates to management's ability to predict changes in the environment and within the organization itself. If the organization does not adapt, its survival is threatened.

\section{e. Development}

Organizations must invest in the organization itself to expand its ability to survive in the long term. The usual development effort is a training program for management and non-management personnel, but nowadays organizational development has many kinds and includes a number of psychological and sociological approaches.

The term administration relates to the process of cooperating two or more people in achieving mutually agreed goals. By nature, humans need each other in fulfilling their daily needs, both material (physical needs) and immaterial (biological and psychological needs). Given these needs are limited in nature and difficult to obtain if done individually, so to realize these desires requires cooperation between them.

Cooperation is a series carried out by a group of people together, regularly and directed on the basis of division of tasks according to mutual agreement. The activities of a group of people based on cooperation are actually a phenomenon that is universal (do not know time and place) that has been going on since the emergence of human civilization up to the modern age as it is today. Almost all activities in human life whose activities are carried out together, will be found by a group of people who work together to achieve the desired goals together. From this description, it can be seen that the point of administration is moving within groups and carried out by groups. 
The notion of administration has been put forward by several experts. Siagian (2002: 2) suggests the notion of administration: Administration is the entire process of implementing the decisions that have been taken and the implementation is generally carried out by two or more people to achieve predetermined goals.

The science that studies the phenomenon of cooperation that is cooperative and organized to achieve goals is the science of administration. The phenomenon of cooperation that is cooperative and organized becomes a center for administrative science studies, the phenomenon of cooperation carried out by and the public becomes a center for administrative studies (public administration), the phenomenon of cooperation carried out by and is private becomes the study of commercial administration science (business administration) ) and the phenomenon of cooperation between countries and between individuals or organizations that cross national borders is a study of international administration (international administration).

A group of people who wish to achieve goals, but the process of their activities is not based on regular cooperation, this cannot be called administration. A group of people who work together to achieve a goal, but in this cooperation there is a group of people, the division of tasks and goals to be achieved, but if the means to achieve these goals are not systematically arranged, this cannot be called administration. This provides an understanding that not all collaborative activities carried out by a group of people can be referred to as administration.

The opinion of the administrative experts states that in this administrative process, activities include thinking and implementing, starting from plans to obtain profits or to achieve goals. These elements and processes are interwoven to form a system.

The definitions of administration as expressed by some experts in essence explain that administration is a process of cooperation of two or more people who have the same interests (in which there is a process of planning, organizing, controlling and supervising) in an effort to achieve mutually agreed goals. It will be found in the administrative sense that there is cooperation between two or more people, there are activities that will be carried out with the same interests and there are goals to be achieved.

Silalahi (1999: 12) describes some of the main characteristics of administration, namely:

1. The existence of a group of people, meaning that administrative activities are only possible if carried out by more than one person.

2. The existence of cooperation, meaning that administrative activities are only possible if two or more people work together.

3. The existence of a division of tasks, meaning that administrative activities are not just cooperative activities, but that cooperation must be based on a clear division of labor.

4. The existence of coherent activities in a process, meaning that administrative activities take place in certain stages on an ongoing basis.

5. There is a goal, meaning that administrative activities are carried out because of the desire to be achieved through cooperative activities.

John M. Pfiffner in Sugandha (1995: 65) says that "administration is an activity or process, primarily related to the means to carry out predetermined goals".

Public administration, better known in Indonesia as state public administration, is one aspect of government activities. Public administration is one part of administrative science which is closely related to the formulation of various state policies. Therefore, public administration is very influential not only on the level of formulation but also at the level of policy implementation, because indeed public administration functions to achieve program objectives that have been determined by political policy makers.

Public administration is the process of determining and achieving state goals by using all available resources efficiently through its officials in an organized and coordinated manner by implementing planning, decision-making, resource 
management, persuasion, leadership and assessment and supervision. Pffifner and Sherwaad in Suradinata (1998: 2) say that "Administration may be defined as the organization and material resources to achieve desired ends".

Meanwhile, Tjokroamidjojo (1997: 13) suggests the following formulation of Public Administration:

1. A study of how various government agencies are organized, equipped with personnel, financed, mobilized and led.

2. Management and organization of people and their tools to achieve government goals.

3. Government activities in exercising its political power.

4. Science that studies the implementation of state politics.

Based on these opinions, it can be concluded that public administration is the whole administration of state power by utilizing all the capabilities of the apparatus as well as all funds and resources for the achievement of state objectives and the carrying out of government tasks. In Indonesian public administration, it is often the term public that can be interpreted as government, in this case there is a relationship between the role of government in carrying out the role of public services.

Public administration in a broad sense the object is the state, while government administration is public administration in a narrow sense, the object is the government in the administration of government. From this formula, Tjokroamidjojo (1997: 3) suggests the following main elements of public administration:

1. Aim. There are goals or policies that need to be set and worked on to be achieved.

2. Cooperation. Public administration is a form of cooperation between people and institutions.

3. Activity process. The existence of an orderly process of business activities, controlling business in planning, implementing, controlling and supervising the achievement of goals.

4. Means. The existence of facilities in the form of power and funds (including equipment)
Furthermore, Tjokroamidjojo (1997: 3) states the main criteria that underlie the implementation of public administration as follows:

1. Rationality. So that the implementation of public administration is more rational.

2. Effectiveness. In order for the implementation of public administration to achieve more results as planned, to achieve the goals achieved more effectively.

Administration is an art of getting things done. Emphasis is placed on processes and methods to ensure effective action. On the other hand, it does not have a single meaning. The term encompasses the whole complex of values, attitudes, and actions. In terms of or material, public administration is carrying out policies, namely establishing and implementing policies in terms of formality or form, public administration is binding decision-making, so public administration includes determining the direction of action and following that direction.

The success or failure of an organization in carrying out its activities depends on the people who are its members. The activity of an organization according to Silalahi (2002: $137)$ is defined as: "the activity of utilizing human and material resources in an organizational collaboration through the process of planning, organizing, monitoring, to achieve organizational goals efficiently and effectively while the ability to lead, direct and move the organization to achieve the goal is called "managerial leadership".

\section{Conclusion}

The formation of work units within the organization is an attempt to fulfill the need to achieve goals. The work unit must always have a main task and function as a basis for determining plans. Management has a function that must be performed in every activity, because it has become a necessity and to support the success in achieving organizational goals. The management function must be able to carry out activities in a practical manner so that organizational goals can be achieved effectively. Therefore, various factors that determine the implementation of activities need careful attention and adjusted on the basis of needs at any time. 


\section{References}

Handayaningrat, Soewarno. 1995. Introduction to Administration and Management Studies. Jakarta: Mount Agung.

Siagian. 1997. Personnel Management. Issue four. Jakarta: Erlangga

Nitisemito, Alex S. 1981. Personnel Management (Human Resource Management). Jakarta: Ghalia Indonesia.

Stoner and Freeman. 1994. Human Resources Management for Public Administration. Perntice Hall.

Sugandha, Dann. 1991. Coordinating Tool for Unifying Administrative Movement, Jakarta: Intermedia.

Steers, Richard. 1985. Organizational Effectiveness, translating Magdalene, Jakarta: Erlangga.

Hasibuan, Malayu. 1999. Organization and Motivation, Jakarta: Earth Literacy.

Gibson, Ivancevich \& Donnely. 1994, Organization and Management, Behavior, Structure, Process, translation Djoerban Wahid, Jakarta: Rajawali. 